\title{
GAMIMA-RAY SPECTROMETRY FOR DISTINGUISHING ACID AND BASIC ROCKS OF THE SERRA GERAL FORMATION, IN THE SERRA GAÚCHA WINE REGION, BRAZIL
}

\author{
Rudi César Comiotto Modena ${ }^{1}$, Rosemary Hoff², André Rodrigo Farias ${ }^{3}$, \\ Jorge Antônio Viel ${ }^{4}$ and Osmar Gustavo Wöhl Coelho ${ }^{5}$
}

\begin{abstract}
The gamma-ray spectrometric research has allowed for observation of the distribution of radioactive elements such as $\mathrm{K}, \mathrm{U}$ and Th for recognizing the radioactive signatures of different rock types. The objective of this study was to evaluate the possibility to distinguish between acid and basic rocks of the Serra Geral Formation, in the Serra Gaúcha wine region in the state of Rio Grande do Sul (Brazil) through gamma-ray spectrometry techniques. This study contributed to geologically characterize areas of geographical appellation for different wine terroirs. In the study area, the mapping of the lithological variations was conducted through gamma-ray spectrometry field measurements. The method was effective in distinguishing between acid and basic volcanic rocks. For non-weathered rocks, all four channels (CT, K, $\mathrm{eU}$ and $\mathrm{eTh}$ ) were efficient, but for weathered rocks, only the measurements of eU and eTh were effective. The method distinguished three types of volcanic rock such as acid, basic and breccia and being a contributor to soil studies, pointing out places where the traditional vitiviniculture could be expanded.
\end{abstract}

Keywords: geophysical method, wine terroir, volcanic rock.

RESUMO. A pesquisa por gamaespectrometria tem permitido observar a distribuição de elementos radioativos, tais como K, $\mathrm{U}$ e Th reconhecendo as assinaturas radioativas de diferentes tipos de rocha. 0 objetivo deste estudo foi avaliar a possibilidade de distinguir entre as rochas ácidas e básicas da Formação Serra Geral, na região vitivinícola Serra Gaúcha, no estado do Rio Grande do Sul (Brasil) por meio de técnicas de gamaespectrometria. Este estudo caracterizou a geologia de áreas de indicação geográfica de diferentes terroirs vinícolas. Na área de estudo, o reconhecimento de variações litológicas e a pesquisa de gamaespectrometria foi realizada através de medições de campo para mapeamento. 0 método foi eficaz na distinção entre rochas vulcânicas ácidas e básicas. Para as rochas não intemperizadas todos os quatro canais (CT, K, eU e eTh) foram eficientes, mas para as rochas alteradas, apenas as medidas de eU e eTh se mostraram eficazes. 0 método distinguiu três tipos de rochas, como vulcânicas básicas e ácidas e ainda brechas, podendo contribuir para os estudos do solo e mostrando os lugares onde a viticultura tradicional pode ser expandida.

Palavras-chave: métodos geofísicos, terroir vitivinícola, rocha vulcânica.

\footnotetext{
1 Universidade Federal do Rio Grande do Sul - UFRGS, Programa de Pós-Graduação em Engenharia de Minas, Metalurgia e de Materiais, Av. Bento Gonçalves, 9500, Setor 4 - prédio 74, Campus do Vale, 91501-970 Porto Alegre, RS, Brazil. Phone/Fax: +55(51) 3308-9475 - E-mail: rudi.modena@yahoo.com.br 2Empresa Brasileira de Pesquisa Agropecuária - Embrapa Uva e Vinho, Rua Livramento, 515, Caixa Postal 130, 95701-008 Bento Gonçalves, RS, Brazil. Phone/Fax: $+55(54) 3455-8025$ - E-mail: rose.hoff@embrapa.br

${ }^{3}$ Empresa Brasileira de Pesquisa Agropecuária - Embrapa Gestão Territorial, Av. Soldado Passarinho, 303, Fazenda Chapadão, 13070-115 Campinas, SP, Brazil. Phone/Fax: +55(19) 3211-6200 - E-mail: andre.farias@embrapa.br

${ }^{4}$ Universidade Federal do Rio Grande do Sul - UFRGS, Programa de Pós-Graduação em Sensoriamento Remoto, Av. Bento Gonçalves, 9500, prédio 44202, Campus do Vale, 91501-970 Porto Alegre, RS, Brazil. Phone/Fax: +55(51)3308-7477 - E-mail: ja-viel89@hotmail.com

5 Universidade do Vale do Rio dos Sinos - UNISInOS, Av. Unisinos, 950, Bairro Cristo Rei, 93022-750 São Leopoldo, RS, Brazil. Phone/Fax: +55(51) 3591-1122

- E-mail: osmar@unisinos.br
} 


\section{INTRODUCTION}

In Brazil, studies of zoning in wine regions have contributed to the development of geographical appellations and the geologic criteria have been a subject of research. The "Serra Gaúcha" region, main producer of wine in Brazil, has a geodiversity that induced the formation of soils and terrain, comprising natural and cultural factors that imply different agronomic responses for vine and wine. These aspects can value the production of wines with unique qualities, which can define different terroirs. The region is at the limit of the geomorphologic units "Serra Geral" and "Planalto dos Campos Gerais", generated from the rocks of the "Serra Geral" Formation, originated 131 million years ago during a volcanic event of continental extension. The geographical appellations for wine are located mainly in terrains over rocks of the "Caxias" Facies of "Serra Geral" Formation, which is composed of intermediate to acid rocks (rhyolite and rhyodacite), also occurring in minor areas in Gramado facies (basalt). The areas cultivated with vineyards are mainly located on higher altitudes and flat terrains, on the tops of the plateaus. The limit between the two facies of "Serra Geral" Formation is not precise, and it may be solved by employing geotechnology, such as gamma-ray spectrometry.

Knowledge of geodiversity leads to the identification of the characteristics of the physical environment of an area, such as mineral resources, the geological risks and natural landscapes inherent to a region composed of specific types of rocks, relief, soil and climate (Pfaltzgraff \& Viero, 2010). In the "Serra Gaúcha" wine region, the geodiversity of rocks influences the landscape and soil formation, leading to agronomic responses of the vine, which can differentiate the wine production that characterizes different terroirs, according to studies on different wine regions in Southern Brazil (Hoff et al., 2010; 2012; and 2015).

According to Kearey et al. (2009), from the geophysical methods, gamma-ray spectrometry is useful in geological mapping, as the distinctive radioactive signatures, characterized by the distribution of the concentrations of uranium, thorium and potassium radioactive elements, can be used to identify different rock types. Therefore, this method was chosen to assist the elaboration of a geological outline of the study area.

This study aims to evaluate the possibility to distinguish between acid and basic rocks of the "Serra Geral" Formation, in the "Serra Gaúcha" wine region in the state of Rio Grande do Sul, Brazil, through ground gamma-ray spectrometry in order to contribute to the characterization of geographical appellation wine areas. In this context, this study's purpose is to contribute to the knowledge of the geology of the wine region, since the existing geological surveys were made only at regional scales 1:250:000 (IBGE, 2003) and 1: 750:000 (Wildner et al., 2008).
The study area covered approximately $830 \mathrm{~km}^{2}$ in the "Serra Gaúcha" wine region in the state of Rio Grande do Sul (Fig. 1). This area comprehends a cross section of the production grapes in this wine region, across several landscapes. The landforms are related to the intense volcanism that occurred in the Mesozoic era (130 million to 132 million years), resulting in a massif with basic lavas at the base and acid lavas on top (700 m altitude), forming peculiar land levels, featuring a unique viticultural landscape.

\section{GAMMA-RAY SPECTROMETRY}

Gamma-ray spectrometry is a useful geophysical method in geological mapping, due to the distinctive radioactive signatures that can be used to identify different types of rock. The most important elements in radiometric research are uranium $\left({ }^{238} \mathrm{U}\right)$, thorium $\left({ }^{232} \mathrm{Th}\right)$ and potassium $\left({ }^{40} \mathrm{~K}\right)$. The emission of gamma-rays is generated immediately after the occurrence of decay, but sometimes at intervals of a few hours. Their low energy levels allow them to penetrate only on 30 to $40 \mathrm{~cm}$ in rocks and soils (Ulbrich et al., 2009). The gamma-ray spectrometry works by the principle of registration of the gamma-ray spectrum using detectors consisting of sodium iodide crystals activated by thallium. When gamma-rays enter the crystals, they interact with their electrons, leaving them in an excited energy state. When the electrons return to the original state, they emit photons, which is the energy produced by atomic or nuclear transition processes. The number of photons emitted is proportional to the energy of the gammarays intensity and the captured light is a measure of the incident energy. The wavelength of light measured by the detector is converted into an electrical signal by a set of photomultiplier tubes to be digitally processed (Grant, 1982).

Gamma-rays are absorbed or scattered by matter with partial or total loss of power due to the influence of the physical interactions known as Compton effect, photoelectric effect and pair production. Only the Compton effect operates in the spectral range defined by the peaks of interest in geological prospecting, between 1.46 and $2.62 \mathrm{MeV}$.

From the elements used in geophysical prospecting, potassium is responsible for about $98 \%$ of the radiation emitted from the soil and rocks. The gamma-ray emissions resulting from the uranium and thorium are determined from the decay series products, respectively bismuth $-\mathrm{Bi}^{214}$ and thallium $-\mathrm{T}^{208}$. The gamma-ray radiation emission spectra are characterized by different energy peaks. Potassium is identified and quantified by the instrument by absorbing an energy of $1.46 \mathrm{MeV}$, corresponding to the unique natural isotope $\left({ }^{40} \mathrm{~K}\right)$, which represents $0.012 \%$ of the total $\mathrm{K}$ contents. The other isotopes, ${ }^{39} \mathrm{~K}$ and ${ }^{41} \mathrm{~K}$ 


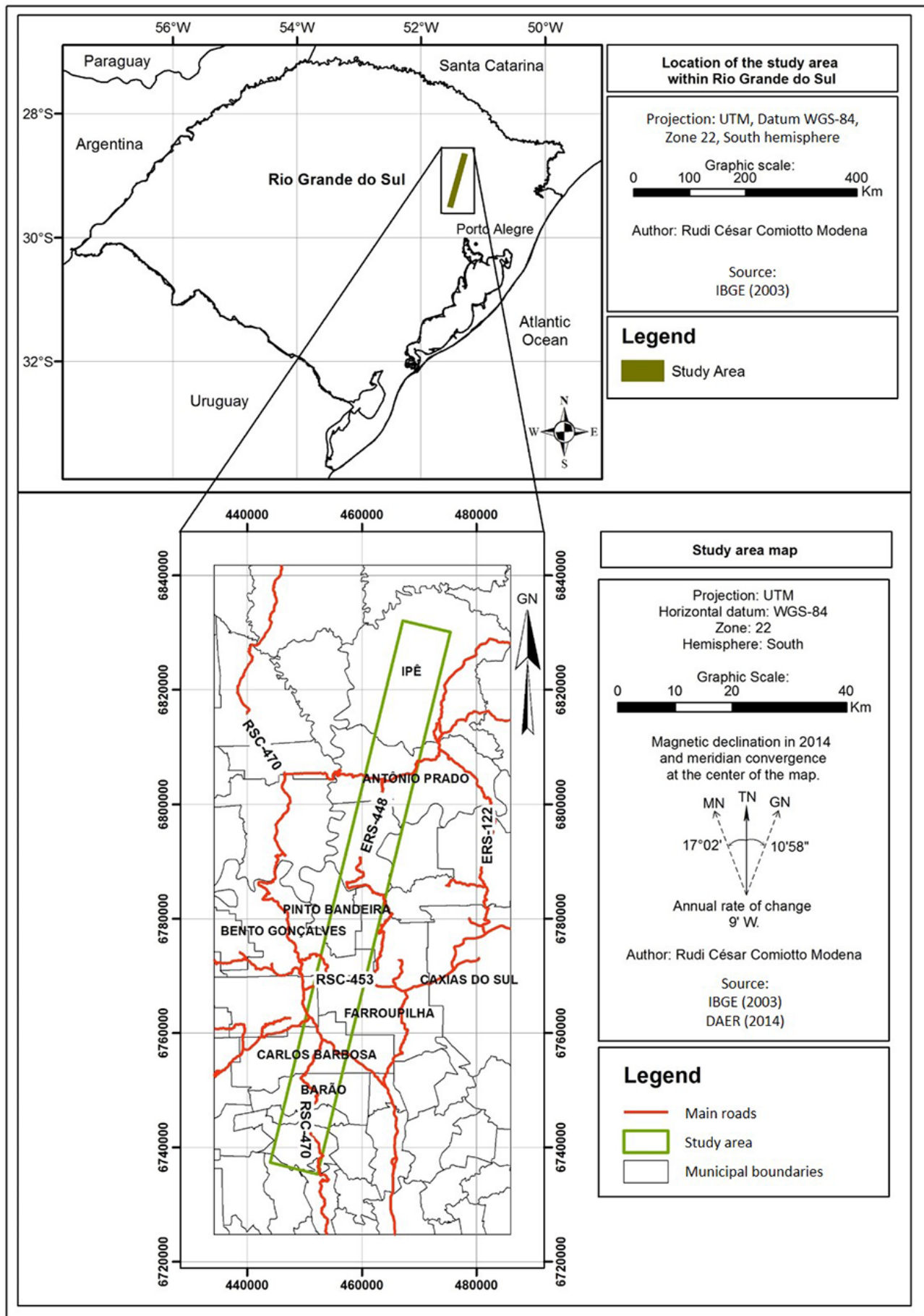

Figure 1 - Location of the study area (green rectangle), showing the main roads and cities.

are non-radioactive and represent, respectively, $93.26 \%$ and $6.73 \%$ of content (Becegato \& Ferreira, 2005). Therefore, gammaray spectrometry can be considered as a direct measurement of the amount of K (Dickson \& Scott, 1997).
The natural uranium isotopes are a mixture of mainly ${ }^{238} \mathrm{U}$ $(99.3 \%)$ and ${ }^{235} \mathrm{U}(0.7 \%)$, representing complex decay chains, which terminate in the stable isotopes ${ }^{206} \mathrm{~Pb}$ and ${ }^{207} \mathrm{~Pb}$, respectively. Uranium is detected by the $1.76 \mathrm{MeV}$ energy peak that 
corresponds to the absorption of ${ }^{214} \mathrm{Bi}$ of the ${ }^{238} \mathrm{U}$ series, used to identify and quantify natural uranium (Becegato \& Ferreira, 2005). Measurements should be ideally made in radioactive equilibrium conditions, difficult to achieve, because the ${ }^{238} \mathrm{U}$ decay series requires an approximate time of 1.5 million years. Another problem encountered is the possibility of separation of the various isotopes derivatives, due to their very different behavior and geochemical properties. Therefore, measurements made in radioactive imbalance no longer represent the original concentration of uranium in rock or soils (Ulbrich et al., 2009).

The analysis of gamma-ray from ${ }^{238} \mathrm{U}$ and ${ }^{232} \mathrm{Th}$ in the naturally occurring materials considers the detected intensity of radiation emanating from the products of radioactive decay series, ${ }^{208} \mathrm{TI}$ and ${ }^{214} \mathrm{Bi}$ atoms, respectively. Then, the counting rate should be related to the amount of original atoms, if it is assumed that there is a direct relationship between the amount of original atoms and their daughters. This is correct when the radioactive decay series is in radioactive equilibrium (Killeen, 1979).

Natural thorium is essentially composed of the ${ }^{232} \mathrm{Th}$ isotope and its decay products, representing $100 \%$ of Th (Becegato \& Ferreira, 2005). It is identified by the ${ }^{208} \mathrm{TI}$ peak, corresponding to an absorption energy of 2.62 MeV. Due to the short half-lives of the thorium decay series, the time required to establish radiative equilibrium is about 40 years. Thus, gamma radiation represents a good measure of the thorium concentration (Dickson \& Scott, 1997). As uranium and thorium concentrations are determined indirectly by gamma-ray spectrometers, their measurements results are called uranium equivalent (eU) and thorium equivalent (eTh), respectively. Dickson \& Scott (1997) made gamma-ray spectrometric measurements, in laboratory, of different samples of Australian rocks and soils. The analysis of the average radioelements concentrations in igneous rocks found that there is a correlation between the increase in such concentrations and increasing silica contents.

According to Ulbrich et al. (2009), important variations can be caused by the sharp mobilization of the three radioelements by hydrothermal alteration, especially caused by weathering in tropical or sub-tropical regions with high rainfall rates. Often, granitic rocks in these regions are covered by thick soils, showing a decrease in $\mathrm{K}$. Thorium measurements can be expected to be consistent, or very similar, with the original fresh rock concentrations, though in some cases enrichment is possible due to the accumulation of residual grains in the soil. However, the increased solubility of uranium permits; allows its migration, partially decreasing the concentration of this element in soils and weathered rocks.
The relative and absolute abundance of the equivalent elements $\mathrm{U}$, Th and $\mathrm{K}$, determined by gamma-ray spectrometry, can aid in the characterization of many rock types, especially those subjected to weathering processes at the first $30 \mathrm{~cm}$ of rock or soil. The highest concentrations of these elements occur in granitic rocks, because of their geochemical properties, like the enrichment in the more differentiated series of magmatism, especially in pegmatites. The concentrations of $\mathrm{U}$ and Th can also increase in biotite granites, modified leucogranite and alkaline granites. However, the U/Th ratio of these rocks can be highly variable due to differences in oxidation caused by late processes (Yeats et al., 1982). Much of the $U$ and Th present in igneous rocks is concentrated in accessory minerals such as zircon, apatite and sphene.

Other highly radioactive minerals rich in $\mathrm{U}$ and Th are monazite, allanite, pitchblende, thorite and pyrochlore. These minerals are minor rocks constituents and are widely distributed, not allowing high concentrations. K-feldspar and mica contain higher concentrations of $\mathrm{K}$, and it is possible to distinguish rocks containing different amounts of these minerals.

Thorium is a relatively immobile element in its $\mathrm{Th}^{+4}$ oxidation state tending to be concentrated in resistant materials, or to be carried for short distances in the solid state. Therefore, minerals containing Th in their structure, such as zircon and monazite concentrate instead in placer deposits and in the heavy fraction of clastic sediments. Uranium has high geochemical mobility under oxidizing conditions $\left(\mathrm{U}^{+6}\right)$. However, in the $\mathrm{U}^{+4}$ tetravalent oxidation state, its dispersion is limited by the adsorptive precipitated iron hydroxides, oxides and organic material; unless high concentrations of $\mathrm{CO}_{3}^{2-}$ or other complexes are present (Rose \& Wright, 1980). Potassium is a very common element as a constituent of soil, especially when the source rock has K-feldspar, mica and clay minerals that are often transported in colloidal form by groundwater and deposited in clayey sediments.

The relative stability of Th and $\mathrm{K}$ in surficial environments is reflected in the K/Th ratio, where values are often related to lithological boundaries (Darnley, 1993). Weathering is the responsible factor for an important effect on the distribution of radioelements, given by the decrease of the $\mathrm{U} / \mathrm{Th}$ ratio in the altered rocks and may be a guiding factor to exploration of dispersion halos. Based on the principle that changes in the content of radioactive elements $\mathrm{K}^{40}, \mathrm{U}^{238}$ and $\mathrm{Th}^{232}$ would accompany the lithological variations, it is possible to identify classes of rocks correlated with geochemical characteristics, especially for the study of source rock by the presence of uranium.

\section{GEOLOGY}

The studied region is part of the geological context of the "Paraná" Basin, stratigraphically belonging to the "Serra Geral" 
Formation of São Bento Group, as described by Wildner et al. (2008). According to Milani et al. (2007), the "Paraná" Basin can be characterized as a large sedimentary region of the South American continent, which includes parts of Brazil, Paraguay, Argentina and Uruguay territories, covering approximately 1.5 million square kilometers. The "Paraná" Basin comprises a sedimentary-magmatic package with a maximum total thickness of around seven thousand meters; its structural depocenter coincides geographically with the region of the "Paraná" River channel.

According to Frank (2008), the largest volcanic events of the planet formed the continental flood basalt provinces (Large Igneous Provinces - LIPS), characterized by large volumes of lava produced in relatively short periods of time of the order of a few million years. The LIPS are present on all continents and ocean floors, with known occurrences since the Proterozoic, especially between the Mesozoic and Cenozoic eras.

Among the subaerial Large Igneous Provinces (LIPS) of the world, the Cretaceous "Paraná-Etendeka" Continental Flood Basalt Province (CFBP), which includes the "Serra Geral" formation, is ranked as second largest, surpassed only by the Siberian Traps in the Tunguska Basin. This extensive magmatism generated along the newly created continental margins, among other features, the Abutment Plateau and the Walvis Ridge and Rio Grande volcanic chains, which constitute the fossil trace of the migration of the Gondwana fragments (Wildner, 2004). These magmatic episodes are linked to tensor fields and endogenous phenomena that led to the disintegration of Pangaea (Milani et al., 2007), and possibly the magma generation and extraction are related to the mantle dynamic of Tristão da Cunha plume (Wildner, 2004).

Peate et al. (1992) described the strongly bimodal nature of the "Serra Geral" lavas, generally represented by basalts and rhyolites, and featuring a silica gap between $60-64 \%$. The "Serra Geral" Formation consists of $97.5 \%$ of basic rocks and only 2.5\% of acid rock types (Nardy et al., 2008; Lima et al., 2012).

In the early nineties, radiocarbon dates between 138 and 132 Ma were obtained by using the ${ }^{40} \mathrm{Ar} /{ }^{39} \mathrm{Ar}$ technique over twothirds of the NW of the basin. In the SE part of the basin, the ages obtained were between 133 and $127 \mathrm{Ma}$ (Frank, 2008). Wildner et al. (2006), using the U-Pb technique, dated zircons contained in the rocks of the "Chapecó" facies, obtaining $135.5 \pm 2.3$ and $137.3 \pm 1.8 \mathrm{Ma}$ as final ages of volcanism.

According to Wildner et al. (2008), two facies of the "Serra Geral" Formation occur in the study area: "Gramado" facies and "Caxias" facies (Fig. 2). The "Gramado" facies consists of fine grained basaltic to medium melanocratic rocks presenting pa- hoehoe flow structures, with vesicular horizons filled with zeolite, carbonates, apophyllite and saponite.

The "Caxias" facies is characterized by its intermediate composition, consisting of rhyodacites and rhyolites with mesocratic, microgranular, vitreous and spherulitic texture ("carijó" type). It also presents strong tabular disjunction at the top of the lava beds and it is solid in the central portion. Flow folds and breccias are frequent, and their vesicles are filled predominantly by chalcedony and agate, the mineralization source in the area.

In this region, soil surveys showed that rock types are associated with specific soil types, as demonstrated by a regional survey (IBGE, 2003) and a medium scale survey (Flores et al., 2007).

Furthermore, different rocks in the region form different reliefs, some of them more favorable for modern viticulture, using crop mechanization. Usually the rocks of the "Caxias" facies occupy the higher grounds in the "Serra Gaúcha" wine region, with more favorable slopes and better exposure for viticulture. The "Gramado" facies occurs in areas of high slope and shading, with a microclimate less favorable to viticulture. Tonietto et al. (2012) showed that in this region, the differences in climatic characteristics are due to the different altitudes. These differences are related to the two facies of "Serra Geral" Formation and their position on the terrain.

\section{MATERIALS AND METHODS}

Initially a geographic information system (GIS) was created using the ESRI ArcGIS10 program, in which the satellite images, the vector maps and numerical terrain model (NTM) were loaded. The cartographic base used was the "Serra Gaúcha" digital cartographic database at 1:50,000 scale (Hasenack \& Weber, 2007). The local digital network was obtained from IBGE (2003) and the state highways maps from DAER (2014). The geological information was obtained from the Geological Map of Rio Grande do Sul at 1:750,000 scale (Wildner et al., 2008).

The fieldwork was done between January and March 2014. A Garmin Montana 650 GPS unit and topographic maps at $1: 50,000$ scale were used to assist in the location of the areas. For each chosen point, a geological and geomorphological description was written in a field notebook. The GPS unit was used to acquire track and points coordinates and for positioning the photographic records.

The total count (TC), K, $\mathrm{U}$ and Th measurements were made with a portable gamma-ray spectrometer (Radiation Solutions brand Super Spec RS-125 model) with 1024 spectral channels (Radiation Solutions Inc., 2013), borrowed from the Applied Stratigraphy Center (NEAP) - UNISINOS. This equipment was 


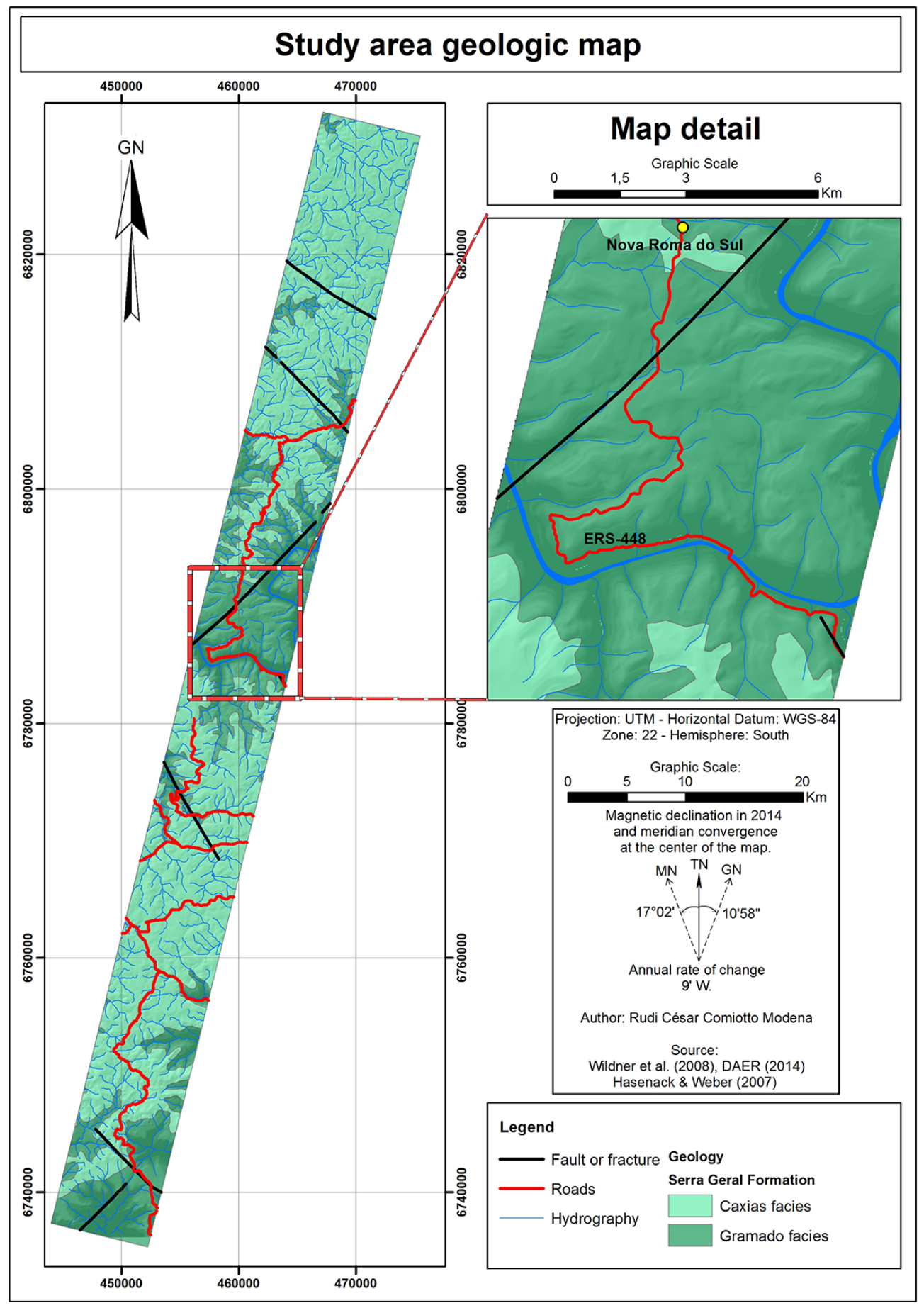

Figure 2 - Geologic map of the study area, "Serra Gaúcha" region, Brazil.

configured to accumulate counts for 180 seconds, as suggested by previous studies (Becegato \& Ferreira, 2005; Silva et al., 2010; Aurich, 2013). The measurements were based on direct physical contact between the equipment and the rock or soil, using the 'Assay' option of the equipment for all readings. The values were saved in the equipment memory and manually recorded in a spreadsheet.

After each field stage, the information was organized for integration into the geographic information system and at the end of the fieldwork, 83 points were obtained. The rating of the rocks 
was based on the information collected in the field. First, the samples were classified by the degree of weathering, according to the criteria for the classification of rock masses (Panitz, 2007).

The gamma-ray spectrometric measurements were organized in a spreadsheet. The information of the four variables (TC, $K$, $\mathrm{eU}$ and eTh) were distributed into 10 equal class intervals, to obtain absolute frequency histograms. A table was created with key information regarding the degree of weathering, facies information and radiometric measurements. For better visualization of the distribution of radiometric information, two types of graphs were generated:

- Individual for TC, K, eU and eTh measurements vs. rock type and degree of weathering;

- $\mathrm{eU} / \mathrm{K}, \mathrm{eTh} / \mathrm{K}$ and $\mathrm{eTh} / \mathrm{U}$ radioelement ratios.

\section{RESULTS AND DISCUSSION}

The samples were classified into three groups of rocks: acid, basic and breccia (Fig. 3). This classification takes into consideration only macroscopic features such as mineralogy, textures and structures. The nomenclature adopted for facies associations was related only to the rocks described in the field. The acid rocks are compatible with the "Caxias" facies and the basic rocks with the "Gramado" facies (Wildner et al., 2008). The breccia group is related to the "Gramado" facies (Wildner et al., 2008) and represents the contact between both types of rocks.

A bimodal trend was identified in the absolute frequency histograms (Fig. 4), being more pronounced in the $\mathrm{K}$ and eTh measurements and less evident in TC and eU. The classes that separate the two trends were the fifth class for TC (33.7 cps to $39.8 \mathrm{cps})$, the fifth one for $\mathrm{K}(2.7 \%$ to $3.2 \%)$, the fourth one for $\mathrm{eU}$ (2.7 ppm to $3.6 \mathrm{ppm})$ and the fourth for eTh (10.8 ppm to $12.8 \mathrm{ppm})$.

By using this technique only, it was possible to define limits that can separate the acid rocks (higher values) from the basic rocks (lower values). This bimodal behavior of the histograms was expected, since according to Peate et al. (1992) there is a strongly bimodal nature of the lavas from "Serra Geral" Formation, generally represented by basalts and rhyolites with a silica gap between $60-64 \%$.

The radioelements concentrations also showed this trend, even though it was possibly attenuated due to the difference between the number of measurements in acid rocks (59), basic rocks (17) and breccia (7), and also because the measurements were performed on rocks with different degrees of weathering (Table 1).
Based on Table 1, there is a greater dispersion in the measurements of $\mathrm{K}$ in acid rocks, with a trend towards lower concentrations of this element as the degree of weathering increases. This observation agrees with Ferreira et al. (2009) and Ulbrich et al. (2009), according to which potassium can be completely leached in tropical and subtropical regions, forming clay minerals that are poor in this element, which explains why the gammaray spectrometric measures in soil and alluvium may register values close or even equal to zero. Therefore, potassium concentrations can present similar values in basic rocks and weathered acid rocks.

Still on acid rocks, there was a similar behavior of the measures of TC and eU. The highest concentrations were observed in the rocks without weathering, decreasing in weathered rocks. It was also observed that the levels of these radioelements decrease as the degree of weathering increases. However, this effect is lower than that presented by potassium. According to Ulbrich et al. (2009), the higher solubility of uranium compounds permits their migration, at least partially decreasing the concentration of this element in soils and modified rocks. However, as noted by Ferreira et al. (2009), in some cases, even with strong weathering, the mobilized uranium can be absorbed by hydroxides, colloids and other compounds in the soil.

Figure 5 presents the most evident eTh behavior, in which the average concentrations remained the same in the various degrees of weathering, causing a reduction in the amplitude of the eTh concentration values with the increasing degree of weathering. Thus, the weathering process has homogenized thorium concentrations in the acid rocks. According to Ulbrich et al. (2009), it was expected that the Th gamma-ray spectrometric measurements indicate contents consistent with the original rock, possibly even presenting some enrichment, because of the accumulation of residual grains in the soil.

Even though thorium showed good results for more weathered rocks, this was the only radioelement that presented a small overlapping range for fresh rocks. Basic rocks ranged from 10.3 to $24 \mathrm{ppm}$ and acid rock from 5.6 to $13.4 \mathrm{ppm}$.

In the basic rocks, the four measured variables showed similar behavior, with potassium showing a slightly larger dispersion. All graphics show an increasing trend in the measurements of slightly weathered rocks in relation to fresh rocks. As discussed before, similar values or even enrichments in Th radioelements could be expected, but it is not as common to happen to other elements. For this; a possible explanation could be the fact that the basic rocks were situated on the slopes and bottoms of the valleys at lower altitudes than the acid rocks thus increasing gamma-ray spectrometric signal. This phenomenon could also be explained 


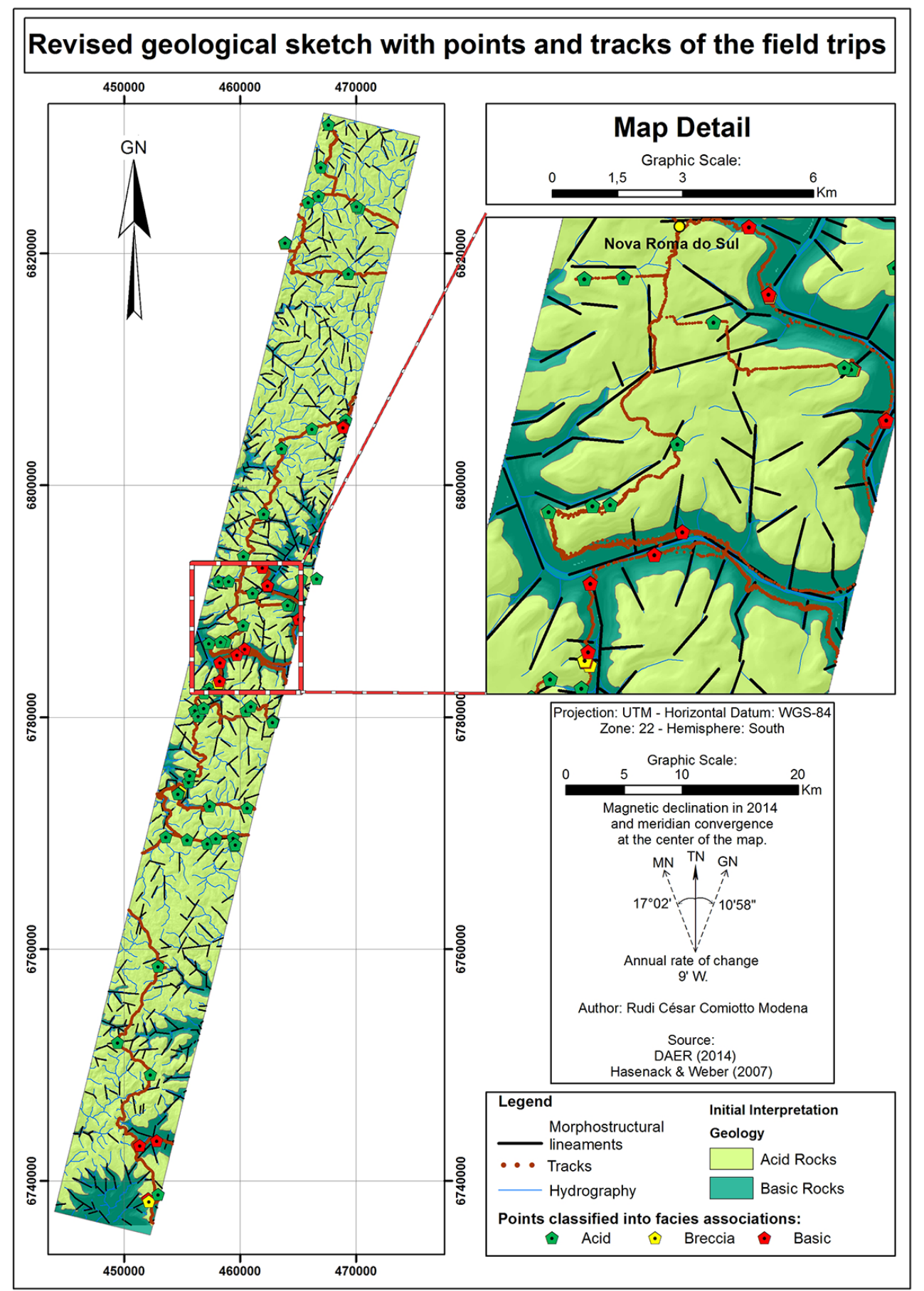

Figure 3 - Points and tracks in the study area, classified by rock association superimposed to the geological map. "Serra Gaúcha" region, Brazil.

as per Ulbrich et al. (2009), by gravity transport of "resistant" mineral grains and the newly formed hosts of Th and $\mathrm{U}$ elements, to lower topographical regions and drainages.

As expected from the field observations, the behavior of breccia was intermediate to the two other rock associations, with measurement values compatible with both, which makes it difficult to separate this facies association from the others by using gamma-ray spectrometry alone.

Among the bivariate graphics, the eTh/eU graphic (Fig. 6) showed the best results in distinguishing the rocks in the study 
TC (cps) histogram

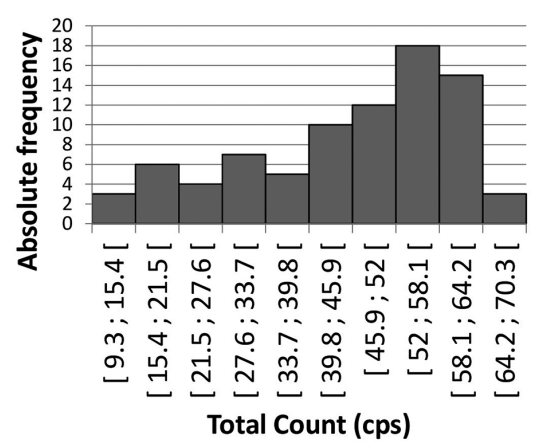

eU (ppm) histogram

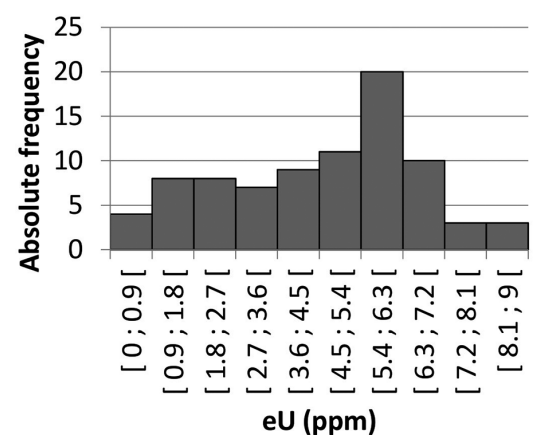

K (\%) histogram

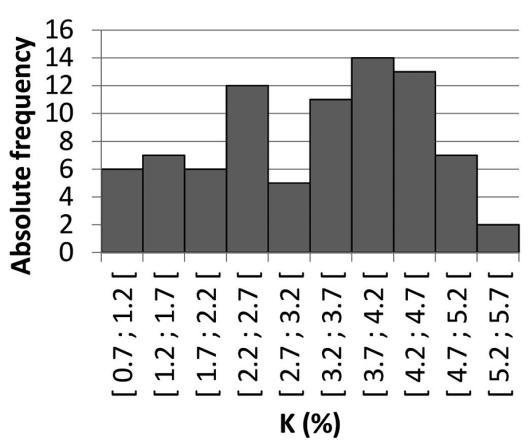

eTh (ppm) histogram

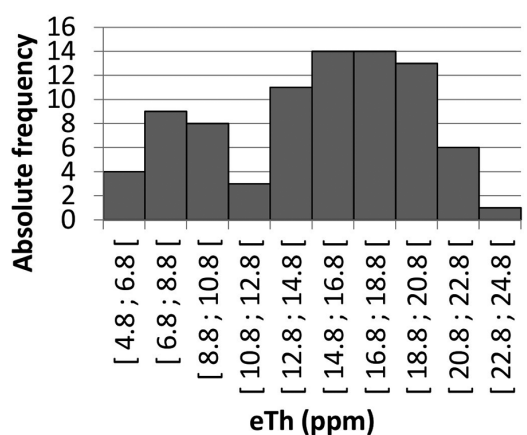

Figure 4 - Absolute frequency histograms of total count (cps), K (\%), eU (ppm) and eTh (ppm) from the measurements on the 83 visited points. "Serra Gaúcha" region, Brazil.

area. In this chart, the measurements associated to acid rocks coincided with felsic volcanic rocks of Dickson \& Scott (1997). However, the basic rocks concentrations correspond to the values of intermediate volcanic rocks in Dickson \& Scott (1997). This is due mainly to the low thorium values found in Australian rocks in comparison to the basalts of "Serra Geral" Formation.

Given the above, the gamma-ray spectrometric survey proved effective in the separation of rocks that occur in the study area. Considering the fresh rocks, all four channels (TC, K, eU and eTh) allowed the distinction between acid and basic rocks. As for the weathered rocks, common in the study area, measurements of eU and eTh are more reliable, as highlighted in Figure 6.

\section{CONCLUSION}

The gamma-ray spectrometry was effective in the separation of acid and basic rocks, including the weathered rocks that are more common in the study area, directly assisting the fieldwork. Considering the fresh rocks, all four channels (TC, K, eU and eTh) allowed for the separation of the two volcanic rock types. As for the weathered rocks, measurements of $\mathrm{eU}$ and $\mathrm{eTh}$ are more reliable, highlighting the use of the eTh $\times$ eU chart (Fig. 6).
These results may contribute to obtain a more detailed geological map of the region, supporting agriculture in the characterization of geographical appellation areas for viticulture as well as studies of the distribution of rocks of the "Serra Geral" Formation.

When the regional geological map (Fig. 2) was compared with this study (Fig. 3), it was updated, explaining that in some places that were previously considered to belong to the "Gramado" facies (basic rock), after this study were characterized as "Caxias" facies (acid rock).

The soil map (Flores et al., 2007) was compared with the geological map and it could be noted that basic rocks are related to "Neossolo" unit (Brazilian Soil Classification - Embrapa, 2006), related to "Gramado" facies. The other types of soil are related to acid rocks that belong to the "Caxias" facies, where the major area of viticulture is located, such as the "Cambissolo" unit, followed by "Argissolo" and "Chernossolo" units. In future detailed studies, the geologic mapping can be supported by ground gammaray spectrometric studies, aiming to differentiate the different soil types.

Gamma-ray spectrometry is a relatively quick and inexpensive method, allowing for optimization in the gathering of geological 
Table 1 - Main information about the gamma-ray spectrometry surveys in "Serra Gaúcha" region, Brazil, showing the concentrations of radioactive elements for acid, breccia and basic rocks. The values are represented by their extreme values (lowest and highest measurement) and the averages are in parentheses. DOW = Degree of weathering: fresh (1), slightly weathered (2), moderately weathered (3), highly weathered (4); completely weathered (5) and all degrees of weathering of the same facies association together (All). $n=$ number of points, $\mathrm{TC}=$ total count, $\mathrm{K}=$ potassium, eU $=$ equivalent Uranium, $\mathrm{eTh}=$ equivalent Thorium, NTM = numerical terrain model.

\begin{tabular}{|c|c|c|c|c|c|c|c|}
\hline $\begin{array}{c}\text { Facies } \\
\text { association }\end{array}$ & DOW & $n$ & $\begin{array}{l}\text { TC } \\
\text { (cps) }\end{array}$ & $\begin{array}{c}K \\
(\%)\end{array}$ & $\begin{array}{c}\mathrm{eU} \\
(\mathrm{ppm})\end{array}$ & $\begin{array}{c}\text { eTh } \\
\text { (ppm) }\end{array}$ & $\begin{array}{c}\text { Elevation NTM } \\
(\mathrm{m})\end{array}$ \\
\hline \multirow{6}{*}{ Acid rocks } & 1 & 37 & $\begin{array}{c}38-71 \\
(56)\end{array}$ & $\begin{array}{c}2.5-5.4 \\
(4.03)\end{array}$ & $\begin{array}{c}2.9-8.9 \\
(5.85)\end{array}$ & $\begin{array}{l}10.3-24 \\
(17.33)\end{array}$ & 398-794 \\
\hline & 2 & 8 & $\begin{array}{c}43-63 \\
(51)\end{array}$ & $\begin{array}{l}2.1-4.8 \\
(3.54)\end{array}$ & $\begin{array}{l}4.2-6.7 \\
(5.28)\end{array}$ & $\begin{array}{l}10.3-24 \\
(16.41)\end{array}$ & $546-751$ \\
\hline & 3 & 4 & $\begin{array}{c}42-53 \\
(47)\end{array}$ & $\begin{array}{l}2.5-4.1 \\
(3.08)\end{array}$ & $\begin{array}{c}3.8-5.4 \\
(4.58)\end{array}$ & $\begin{array}{l}14.5-22 \\
(18.55)\end{array}$ & $578-640$ \\
\hline & 4 & 6 & $\begin{array}{c}32-56 \\
(45)\end{array}$ & $\begin{array}{l}1.4-4.6 \\
(2.82)\end{array}$ & $\begin{array}{c}2.7-5.9 \\
(4)\end{array}$ & $\begin{array}{c}15.7-20.4 \\
(18.45)\end{array}$ & 478-796 \\
\hline & 5 & 4 & $\begin{array}{c}36-55 \\
(46)\end{array}$ & $\begin{array}{c}0.7-3.9 \\
(2.4)\end{array}$ & $\begin{array}{c}4.4-5.9 \\
(5.3)\end{array}$ & $\begin{array}{c}16.1-17.5 \\
(16.73)\end{array}$ & $636-650$ \\
\hline & All & 59 & $\begin{array}{c}32-71 \\
(53)\end{array}$ & $\begin{array}{c}0.7-5.4 \\
(3.66) \\
\end{array}$ & $\begin{array}{c}2.7-8.9 \\
(5.46) \\
\end{array}$ & $\begin{array}{l}10.3-24 \\
(17.33) \\
\end{array}$ & $398-796$ \\
\hline \multirow{3}{*}{ Breccia rocks } & 2 & 6 & $\begin{array}{c}14-58 \\
(36)\end{array}$ & $\begin{array}{c}0.8-4.4 \\
(2.7)\end{array}$ & $\begin{array}{l}1.2-6.5 \\
(3.32)\end{array}$ & $\begin{array}{c}5.1-16.3 \\
(10.55)\end{array}$ & $257-555$ \\
\hline & 4 & 1 & 24 & 2 & 1.6 & 9.8 & 346 \\
\hline & All & 7 & $\begin{array}{c}14-58 \\
(34) \\
\end{array}$ & $\begin{array}{c}0.8-4.4 \\
(2.6) \\
\end{array}$ & $\begin{array}{c}1.2-6.5 \\
(3.07) \\
\end{array}$ & $\begin{array}{c}5.1-16.3 \\
(10.44) \\
\end{array}$ & 257-555 \\
\hline \multirow{4}{*}{ Basic rocks } & 1 & 11 & $\begin{array}{c}16-29 \\
(22)\end{array}$ & $\begin{array}{c}0.8-2.5 \\
(1.54) \\
\end{array}$ & $\begin{array}{l}0.1-2.4 \\
(1.45)\end{array}$ & $\begin{array}{c}5.6-13.4 \\
(8.18)\end{array}$ & 196-489 \\
\hline & 2 & 5 & $\begin{array}{c}14-40 \\
(32)\end{array}$ & $\begin{array}{l}0.9-3.7 \\
(2.64)\end{array}$ & $\begin{array}{c}0.7-2.6 \\
(2.1)\end{array}$ & $\begin{array}{c}7.3-14.7 \\
(10.42)\end{array}$ & $186-410$ \\
\hline & 5 & 1 & 9 & 0.9 & 0 & 4.8 & 419 \\
\hline & All & 17 & $\begin{array}{l}9-40 \\
(25)\end{array}$ & $\begin{array}{c}0.8-3.7 \\
(1.82)\end{array}$ & $\begin{array}{l}0-2.6 \\
(1.56)\end{array}$ & $\begin{array}{c}4.8-14.7 \\
(8.64)\end{array}$ & $186-489$ \\
\hline
\end{tabular}

information of an area, when used in conjunction to other methods (e.g. remote sensing).

For other studies, for a higher classification accuracy, the integration of radiometric data with geochemical and petrographic analysis is recommended, as well as increasing the number of measurements in basic rocks.

\section{ACKNOWLEDGEMENTS}

The authors are grateful to Universidade do Vale do Rio dos Sinos - UNISINOS, Brazilian Agriculture Research Corporation - Embrapa Grape and Wine and Geological Survey of Brazil (CPRM).

\section{REFERENCES}

AURICH A. 2013. Levantamento Gamaespectrométrico na Região do Granito Encruzilhada. Graduation Final Project Geology, Universidade do Vale do Rio dos Sinos, São Leopoldo, Brazil, 120 pp.

BECEGATO VA \& FERREIRA FJF. 2005. Gamaespectrometria, resistividade elétrica e susceptibilidade magnética de solos agrícolas no noroeste do estado do Paraná. Brazilian Journal of Geophysics, 23(4): 371-405. Available on: <http://www.scielo.br/scielo.php?script=sci_arttext\&pid $=$ S0102-261X2005000400004\&lang $=p t>$.

DARNLEY AG. 1993. Some notes on the importance of airborne gammaray spectrometry in the International Geochemical Mapping. Journal of Geochemical of Exploration, 49(1/2): 201-212. Available on: 


\section{eTh(ppm) vs. Facies association (Degree of weathering)}

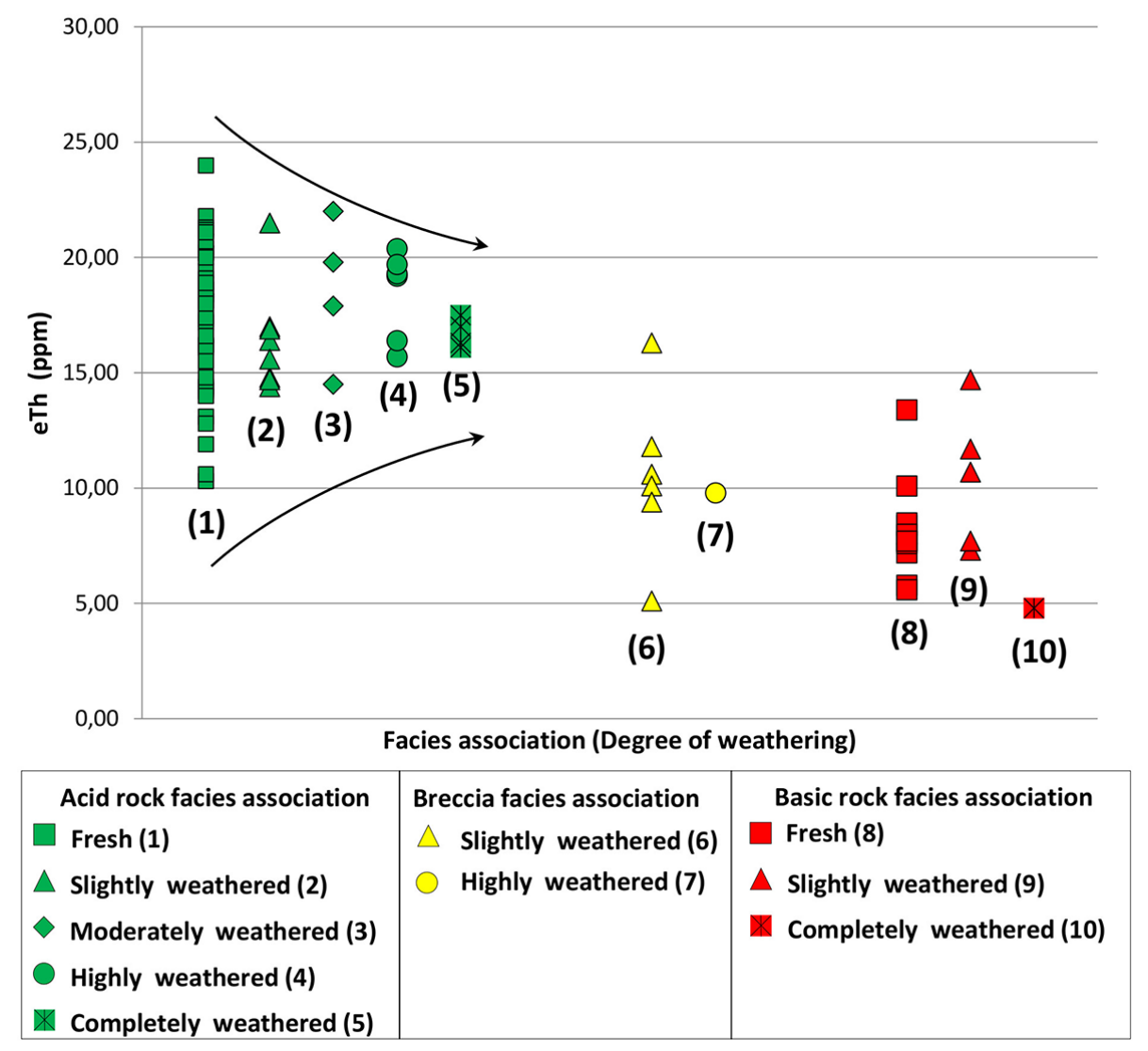

Figure $\mathbf{5}$ - eTh concentration versus rock association (degree of weathering), showing the radiometric measurements. The arrows point out that the weathering process has homogenized the thorium concentration in acid rocks. "Serra Gaúcha" region, Brazil.

$<$ http://ac.els-cdn.com/037567429390045N/1-s2.0-037567429390045Nmain.pdf?_tid=3d13f092-f2fb-11e6-870d-00000aacb35e\&acdnat=1487107335 _3e3ae654323dda3940be4b383e8c47c2>.

DAER - DEPARTAMENTO AUTÔNOMO DE ESTRADAS DE RODAGEM. 2014. Rodovias do DAER. Porto Alegre. Available on: <http://www. geolivre.rs.gov.br/download/rodoviadaer2014rs4326.zip>. Access on: August 30, 2014.

DICKSON BL \& SCOTT KM. 1997. Interpretation of aerial gamma-ray surveys - adding the geochemical factors. AGSO Journal of Australian Geology and Geophysics, 17(2): 187-200. Available on:

$<$ http://www.ga.gov.au/metadata-gateway/metadata/record/81502/>.

EMBRAPA - Empresa Brasileira de Pesquisa Agropecuária. 2006. Brazilian System of Soil Classification. 2nd ed., Centro Nacional de Pesquisa em Solos. Rio de Janeiro, Brazil. Available on:

$<$ http://www.agrolink.com.br/downloads/sistema-brasileiro-declassificacao-dos-solos2006.pdf>. Access on: September 10, 2014.

FERREIRA FJF, FRUCHTING A, GUIMARÃES GB, ALVES LS, MARTIN VMO \& ULBRICH HHGJ. 2009. Levantamentos Gamaespectrométricos em Granitos Diferenciados. II: 0 Exemplo do Granito Joaquim Murtinho, Complexo Granítico Cunhaporanga, Paraná. Geologia USP. Série Científica, 9(1): 55-72. Available on:

$<$ http://www.revistas.usp.br/guspsc/article/viewFile/27456/29228>.

FLORES CA, PÖTTER RO, FASOLO PJ, HASENACK H \& WEBER EJ. 2007. Levantamento semidetalhado de solos: Região da Serra Gaúcha - Rio Grande do Sul. 1:50,000 scale. In: FALCADE I, TONIETTO J, AHLERT S \& HOFF R. Região do COREDE Serra: Mapeamento do Uso e Cobertura do Solo e Classificação Semidetalhada dos Solos. UCS, Caxias do Sul. Available on: <http://www.aune.rs.gov.br/downloads/ planejamento_regional/corede_solos/>. Access on: September 12, 2014.

FRANK HT. 2008. Gênese e Padrões de Distribuição de Minerais Secundários na Formação Serra Geral (Bacia do Paraná). Doctorate Thesis on Geoscience, Programa de Pós-Graduação em Geociências, Universidade Federal do Rio Grande do Sul, Brazil, 322 pp. Available on: <http://www.lume.ufrgs.br/handle/10183/15881>. Access on: November 13, 2015. 

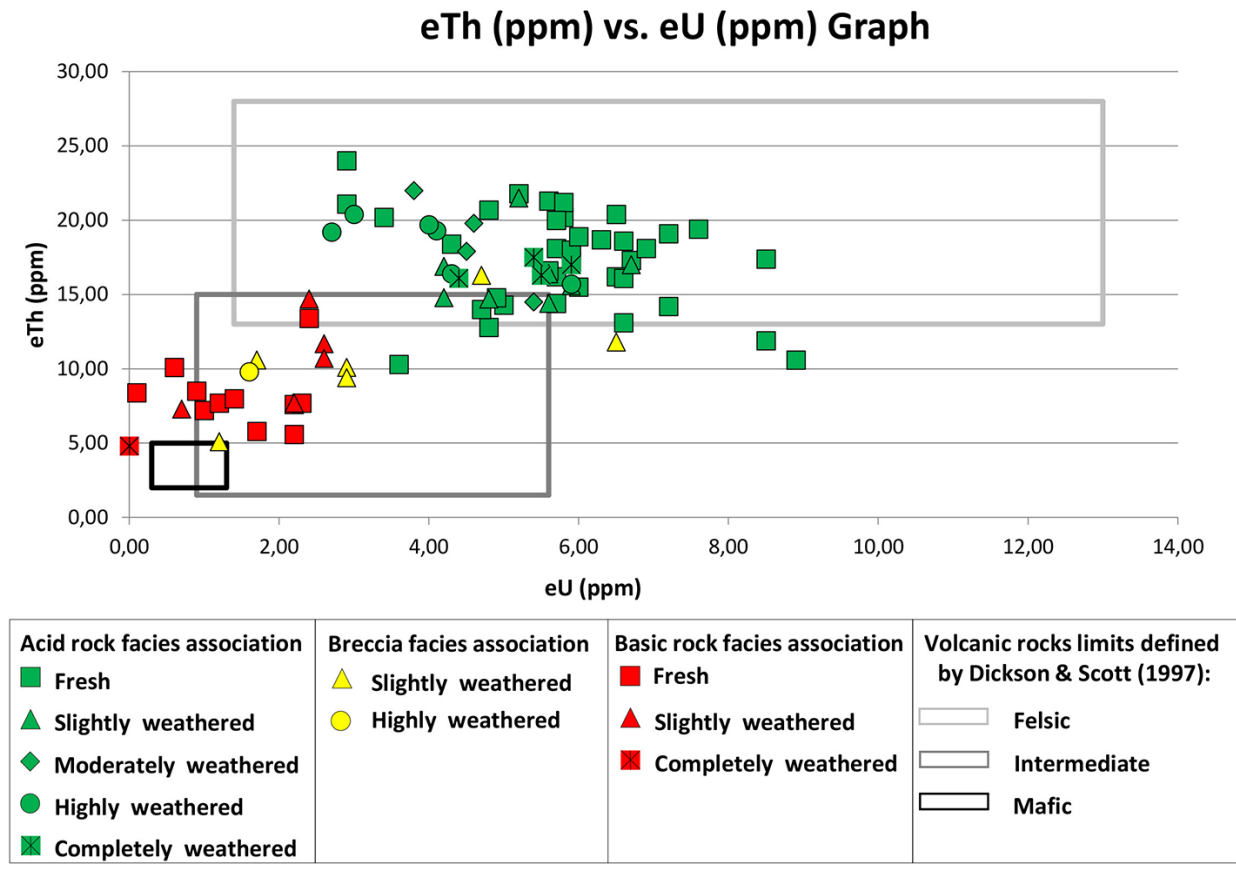

Figure 6 - eTh versus eU graph showing the measurements classified according to the degree of weathering and the facies association. The rectangles correspond to the values found by Dickson \& Scott (1997) for volcanic rocks. "Serra Gaúcha" region, Brazil.

GRANT FS. 1982. Gamma-ray spectrometry for geological mapping and for prospecting. In: Mining Geophysics Workshops, Ontario, Canada, 1982. Cap. 13, p. 13.1-13.27.

HASENACK H \& WEBER EJ. 2007. Base cartográfica digital da Serra Gaúcha, 1:50,000 scale. Porto Alegre, Brazil: UFRGS Centro de Ecologia. 1 CD-ROM. (Série Geoprocessamento n.2). Available on: $<$ https://www.ufrgs.br/labgeo/index.php/dados-espaciais/251-dadosdigitais-espaciais-da-serra-gaucha > . Access on: August 10, 2015.

HOFF R, DUCATI JR \& BERGMANN M. 2010. Geologic and geomorphologic features applied for identification of wine terroir unit by digital image processing, spectroradiometric and GIS techniques in Encruzilhada do Sul, RS, Brazil. In: International Terroir Congress, 8. Soave, 2010. Conegliano: CRA-VIT, 2010. Proceedings... Session 4: p. 44-49. Available on: <http://congresdesterroirs.org/articles/lire/353>. Access on: December 15, 2015.

HOFF R, FALCADE I \& TONIETTO J. 2012. The geology in the context of geographical indications of fine wines in Serra Gaúcha region (Brazil). In: IXe Congrès International des Terroirs Vitivinicoles, Dijon et Reims. Actes Du IXe Congrès International des Terroirs Vitivinicoles. Dijon: Université de Bourgogne, p. 1041-1047. Available on: $<$ http://congresdesterroirs.org/articles/lire/150>. Access on: October 10, 2015.

HOFF R, DUCATI JR, FARIAS AR \& DALCIN M. 2015. Geologia, geomorfologia, sensoriamento remoto e SIG como suporte à caracterização da indicação geográfica Campanha para vinhos de qualidade, RS, Brasil. Feira de Santana: UEFS, 2015. Anais: p. 175-178. Available on: < http://www.alice.cnptia.embrapa.br/alice/bitstream/doc/1038065/1/ GeologiaGeomorfoSIG2015.pdf>. Access on: January 14, 2016.

IBGE - INSTITUTO BRASILEIRO DE GEOGRAFIA E ESTATÍSTICA. 2003. Mapas Temáticos (Geologia, Solos, Vegetação, Geomorfologia) 1:250.000 scale, folhas Passo Fundo (SH.22-V-B) e Caxias do Sul (SH.22-V-D). Rio de Janeiro. Available on: < ftp://geoftp.ibge. gov.br/mapas_tematicos/geologia/cartas_escala_250mil/>. Access on: September 21, 2015.

KEAREY P, BROOKS M \& HILL I. 2009. Geofísica de exploração. Editora Oficina de Textos: São Paulo, Brazil. 438 pp.

KILLEEN PG. 1979. Gamma-ray spectrometric methods in uranium exploration - application and interpretation in geophysics and geochemistry in the search for metallic ores. Geol. Survey of Canada, Economic Geology Report, 31: 163-229. Available on: <https://www. 911metallurgist.com/blog/wp-content/uploads/2015/10/GAMMA-RAYSPECTROMETRIC-METHODS-IN-URANIUM-APPLICATION-ANDINTERPRETATION.pdf $>$.

LIMA EF, PHILIPP RP, RIZZON GC, WAICHEL BL \& ROSSETTI LMM. 2012. Sucessões vulcânicas, modelo de alimentação e geração de domos de lavas ácidos da Formação Serra Geral na região de São Marcos-Antônio Prado (RS). Geologia USP. Série Científica, 2(2): 49-64. Available on: <http://www.revistas.usp.br/guspsc/article/view/ 
45414/49026>.

MILANI EJ, MELO JHG, SOUZA PA, FERNANDES LA \& FRANÇA AB. 2007. Bacia do Paraná. Boletim de Geociências da PETROBRAS, Rio de Janeiro, 5(2): 265-287. Available on: <http://xa.yimg.com/ kq/groups/21920463/2091993927/name/11-Bacia+do+Parana.pdf>.

NARDY AJR, MACHADO FB \& OLIVEIRA MAF. 2008. As Rochas Vulcânicas Mesozóicas Ácidas da Bacia do Paraná: litoestratigrafia e considerações geoquímico-estratigráficas. Revista Brasileira de Geociências, 38(1): 178-195.

PANITZ JSP. 2007. Desenvolvimento e Implementação de Metodologias para a Determinação da Deformabilidade e Tensão em Maciços Gnáissicos. Master Dissertation on Civil Engineering, Programa de PósGraduação em Engenharia Civil, Pontifícia Universidade Católica do Rio de Janeiro, Brazil, 150 pp. Available on: < http://www.maxwell.vrac.pucrio.br/Busca_etds.php?strSecao=resultado\&nrSeq=11328@1>.

PEATE DW, HAWKESWORTH CJ \& MANTOVANI MSM. 1992. Chemical stratigraphy of the Paraná lavas (South America): classification of magma types and their spatial distribution. Bulletin of Volcanology, Berlin, 55: 119-139. Available on: <http://link.springer. com/article/10.1007/BF00301125>.

PFALTZGRAFF PAS \& VIERO AC. 2010. Introdução. In: VIERO AC \& SILVA DRA (Org.). Geodiversidade do Estado do Rio Grande do Sul. Porto Alegre: CPRM, Brazil, p. 10-14. Available on: < http://rigeo. cprm.gov.br/xmlui/handle/doc/16774>. Access on: August 13, 2015.

RADIATION SOLUTIONS INC. 2013. RS-125 Super-SPEC Handheld Radiation Detector. Available on: <http://www.radiationsolutions.ca/ index.php?id=47>. Access on: May 17, 2015.

ROSE AW \& WRIGHT RJ. 1980. Geochemical exploration models for sedimentary uranium deposits. Journal of Geochemical Exploration, 13(2/3): 153-179. Available on: < http://www.sciencedirect.com/ science/article/pii/0375674280900059>.

SILVA SMP, CRÓSTA AP, FERREIRA FJF, BEURLEN H, SILVA AM \& SILVA MRR. 2010. Identificação gamaespectrométrica de placeres rutilo-monazíticos neoproterozóicos no sul da Faixa Seridó, Nordeste do Brasil. Brazilian Journal of Geophysics, 28(1): 61-77. Available on: <http://www.scielo.br/scielo.php?script=sci_arttext\&pid=S0102261X2010000100005>.
TONIETTO J, SOTÉSRUIZ V \& GÓMEZ-MIGUEL VD (Eds.). 2012. Clima, Zonificación y Tipicidad del Vino en Regiones Vitivinícolas Iberoamericanas. Editores técnicos. Madrid. CYTED, 2012. 411 pp. Available on: <http://www.cnpuv.embrapa.br/publica/livro/zonificacion_viticola _cyted_2012.pdf $>$.

ULBRICH HHGJ, ULBRICH MNC, FERREIRA FJF, ALVES LS, GUIMARÃES GB \& FRUCHTING A. 2009. Levantamentos gamaespectrométricos em granitos diferenciados. I: revisão da metodologia e do comportamento geoquímico dos elementos K, Th e U. Geologia USP. Série Científica, 9(1): 33-53. Available on: < http://www.revistas.usp.br/ guspsc/article/view/27455>.

USGS - UNITED STATES GEOLOGICAL SURVEY. 2013. Earth Explorer. Available on: <http://earthexplorer.usgs.gov/>. Access on: May 13, 2015.

WILDNER W. 2004. Estratigrafia do magmatismo Serra Geral na Bacia do Paraná - Conceitos básicos e divisão faciológica. In: SBG, Reunião Aberta da Comissão Brasileira de Estratigrafia, Porto Alegre, Anais, 62-77. Available on: <http://www.geologiadobrasil.com.br/ pdfs/racbe_2004_vf.pdf>. Access on: May 11, 2015.

WILDNER W, ORLANDI FILHO V \& GIFFONI LE. 2006. Itaimbezinho e Fortaleza, RS e SC - Magníficos canyons esculpidos nas escarpas Aparados da Serra do planalto vulcânico da Bacia do Paraná. In: WINGE M, SCHOBBENHAUS C, BERBERT-BORN M, QUEIROZ ET, CAMPOS DA, SOUZA CRG \& FERNANDES ACS (Eds.). Sítios Geológicos e Paleontológicos do Brasil. Available on: <http://sigep.cprm.gov.br/sitio050/ sitio050.pdf>. Access on: May 19, 2015.

WILDNER W, RAMGRAB GE, LOPES RC \& IGLESIAS CMF. 2008. Мapa Geológico do Estado do Rio Grande do Sul, 1:750.000 scale. Porto Alegre: CPRM. Available on: < http://www.cprm.gov.br/publique/media/ geologia_basica/cartografia_regional/mapa_io_grande_sul.pdf $>$. Access on: April 13, 2015.

YEATES AN, WYATT BW \& TUCKER DH. 1982. Application of gammaray spectrometry to prospecting for tin and tungsten granites, particularly within the Lachlan Fold Belt, New South Wales. Economic Geology, 77: 1725-1738. Available on: <http://econgeol.geoscienceworld.org/ content/77/7/1725>. 